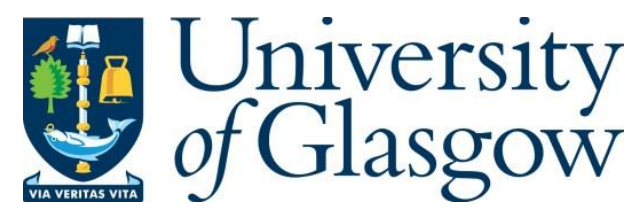

Rose, E. and Busby, N. (2017) Power relations in employment disputes. Journal of Law and Society, 44(4), pp. 674-701.

There may be differences between this version and the published version. You are advised to consult the publisher's version if you wish to cite from it.

This is the peer reviewed version of the following article:

Rose, E. and Busby, N. (2017) Power relations in employment disputes. Journal of Law and Society, 44(4), pp. 674-701, which has been published in final form at $\underline{10.1111 / \text { jols. } 12062}$

This article may be used for non-commercial purposes in accordance with Wiley Terms and Conditions for Self-Archiving.

http://eprints.gla.ac.uk/207723/

Deposited on: 14 January 2020

Enlighten - Research publications by members of the University of Glasgow http://eprints.gla.ac.uk 


\title{
Power Relations in Employment Disputes
}

\author{
Emily Rose*
}

Nicole Busby**

This article reconceptualises the operation of power relations in employment disputes. We draw on Foucault's theory of neo-liberal governance to inform our analysis of empirical data exploring how low income workers make decisions about whether to engage with the Employment Tribunal system. Particular focus is given to the ways the state governs employment disputes to achieve ideologically driven objectives. We conclude: firstly, that power relations in employment disputes operate across a range of institutions and individuals, and that the state's role is powerful and ongoing; secondly, that power relations operate to shape not just the objective context that workers find themselves in when experiencing an employment dispute but also workers' subjective moral codes about appropriate courses of action to take; and thirdly, that despite the powerful influence of the state, workers continue to hold non-economic values that guide their perception of the appropriate basis for relations between employers and workers.

* Law School, University of Strathclyde, Lord Hope Building, 191 St James Road, Glasgow G4 OLT emily.rose@strath.ac.uk

** Law School, University of Strathclyde, Lord Hope Building, 191 St James Road, Glasgow G4 OLT nicole.busby@strath.ac.uk 


\section{INTRODUCTION}

It has long been accepted that power in the employment relationship typically lies with the employer. ${ }^{1}$ Indeed, labour law in the UK developed on the basis that its major objective was to be a countervailing force to counteract the inequality of bargaining power which in inherent and must be inherent in the employment relationship. ${ }^{2}$ Labour law once acted as a countervailing force by facilitating collective bargaining. This assisted workers to define key terms of the employment relationship and provided voluntary procedures for dispute resolution. Today, with the vast decline in union membership, most workers rely on protections afforded by a system of individual employment rights. These rights are enforced through the Employment Tribunal (ET) and civil courts.

There have been a range of procedural changes in the past few years that affect the way that workers are able to assert these individual employment rights in the ET system. Scholars have critiqued these; viewing them as an extension of a neo-liberal policy agenda in which the state acts to facilitate a shift in the balance of power further towards employers. ${ }^{3}$ Particular concern has been raised about the difficulty workers face to gain substantive meaning to statutory rights ${ }^{4}$ and about issues of access to justice more broadly. ${ }^{5}$

Underpinning these analyses appears to be various assumptions about the operation of power in employment disputes. The state is framed as playing a role in setting up the regulatory and structural framework for employment dispute resolution based on its particular ideological position. But, once this is done, power is largely viewed as operating across a binary divide between employers and workers. One side will hold more or less of the tools of power-in terms of the regulatory and structural framework - that they can utilise to their advantage. We submit that this account is partial at best.

In this article we reconceptualise the way in which power relations operate when workers face a problem at work. We do this by drawing on Foucault's theory of neo-liberal governance and applying these ideas to an empirical dataset that captures detail of how low-income workers make decisions about how to engage (or not) with the ET system. Particular focus is given to the ways the state governs the employment dispute process broadly conceived to achieve its ideologically driven objectives.

\footnotetext{
${ }^{1}$ P. Davies and M. Freedland, Kahn-Freund's Labour and the Law (1983).

2 Id.

${ }^{3}$ B. Hepple, 'Back to the Future: Employment Law under the Coalition Government' (2013) 42 Industrial Law J. 3, 213; L. Dickens, 'Fairer Workplaces: Making Employment Rights Effective' in Making Employment Rights Effective: Issues of Enforcement and Compliance, ed. L. Dickens (2012).

${ }^{4}$ Dickens, id.

${ }^{5}$ E. Rose et al., Employment Tribunal Fees: Effect on Clients of Citizens Advice Bureaux (2015a), at $<$ http://www.bristol.ac.uk/media-library/sites/law/documents/Fees\%20report\%205.8.15.pdf>; E. Rose et al., The Price of Justice: The Impact of Employment Tribunal Fees on CAB Clients in Scotland (2015b), at < http://www.cas.org.uk/system/files/publications/The\%20Price\%20of\%20Justice\%20final\%20with\%20cover\%2 0and\%20back.pdf>.
} 
We draw a number of conclusions from our analysis. Firstly, we demonstrate that power relations in employment disputes operate across a range of institutions and individuals. It is not appropriate to view the action as playing out simply between employers and workers. Rather, the role of the state, in particular, is powerful and ongoing. Secondly, we show that power relations operate not just to shape the objective context that workers find themselves in when experiencing an employment dispute but also workers' subjective moral codes about appropriate courses of action to take. This has the effect of promoting economic rationality as the key criteria for decision making about how to pursue, if at all, an employment dispute. It also has the effect of imbuing a particular moral conception about the act of asserting employment rights. Thirdly, we reveal that, despite the powerful influence of the state, workers continue to hold values that fall outside the influence of the state, which guide their perceptions of the appropriate basis for relations between employers and workers. We conclude by suggesting that individual decision-making, which has the illusion of autonomy, is in fact profoundly influenced by state action and that the level of consciousness of this process should be the focus of law and society scholarship.

\section{BACKGROUND}

\section{The ET system and recent changes}

The ET, a specialist tribunal dealing with employment disputes, started life as the Industrial Tribunal when it was established in 1964. In the half century since its establishment, much has changed alongside its name so that the ET has little in common with the original vision underpinning its creation articulated as being to provide an "easily accessible, speedy, informal and inexpensive" route to workplace dispute resolution. ${ }^{6}$

Whether the Donovan Report's ideal was ever achievable is a moot point but empirical research suggests that the reality is shifting ever further from this vision, a trend which looks set to continue as a result of recent policy changes. In reality the ET was never an informal forum based as it is on a party-to-party adversarial process. In addition, employment law has become increasingly complex and legalistic. ${ }^{7}$ The presence of legal representatives in the ET have undoubtedly contributed to its legalism ${ }^{8}$ and, perhaps unsurprisingly, legal representation has been found to play an important role in the outcomes that are achieved in tribunal hearings ${ }^{9}$ detracting further from the realisation of the Donovan vision. The shift from a process of workplace industrial relations governed largely by collectively negotiated agreements towards a system of individualised employment rights led to a rise in the number of claims being made by workers. Successive governments have observed the

\footnotetext{
${ }^{6}$ Report of the Royal Commission on Trade Unions and Employers Associations 1965-1968 (Chairman Lord Donovan, Cmnd 3623), para 572.

${ }^{7}$ Evidenced in part by the rise of employment related legislation, especially from the 1970 s, see G. Morris, 'The Development of Statutory Employment Rights in Britain and Enforcement Mechanisms' in Making Employment Rights Effective: Issues of Enforcement and Compliance, ed. L. Dickens (2012).

${ }^{8}$ See S. Corby and P.L. Latreille, 'Employment Tribunals and the Civil Courts: Isomorphism Exemplified' (2012) 41 Industrial Law J. 4, 387.

${ }^{9}$ H. Genn, 'Tribunals and Informal Justice' (1993) 56 Modern Law Rev. May 3, 393.
} 
cost to the taxpayer of handling claims ${ }^{10}$ and have framed this cost as being problematic casting doubt on the merit of these claims and questioning the motives of workers who bring them. ${ }^{11}$ The broad conclusion being drawn from this is that the high levels of claims made to the ET are acting as a brake on business. ${ }^{12}$

In recent years, the state's problematisation of the current system has led to a number of policy changes that focus on the processes involved in accessing and utilising the ET system, as well as the promotion of alternative forms of dispute resolution. Perhaps the most notable development has been the introduction of fees by the Coalition government in $2013 .{ }^{13}$ Fees are charged at two levels depending on the nature of the claim ( $₫ 390$ for 'simple' Type A claims and $£ 1,200$ for more 'complex' Type B claims). State resourced legal support for workers taking claims to the ET has been severely depleted with the elimination of legal aid for employment cases in England and Wales. ${ }^{14}$ General reductions in funding from central and local government to charities, such as Citizens Advice, that provide free advice on employment disputes, have also been reduced as part of recent austerity measures. ${ }^{15}$

Other changes to the process include the elimination of the ET 'wing members' in 2012 for most cases. ${ }^{16}$ Wing members are representatives from industry and from worker organisations. Tribunal judges can now sit alone. It is also notable, in terms of the utility of the ET system, particularly for workers, that there has been no action taken on the part of government to overcome the problematic system of enforcing awards made by the ET. This is despite a report produced by the Department for Business, Innovation \& Skills stating that only $49 \%$ of workers were paid their award in full and a further $16 \%$ were paid in part. ${ }^{17}$

In terms of alternatives modes of dispute resolution within the ET system, there has been the introduction of Early Conciliation (EC) ${ }^{18}$ which makes it mandatory for potential claimants to notify

\footnotetext{
${ }^{10}$ For example, the statement by Justice Minister Shailesh Vara $\left(28^{\text {th }}\right.$ July 2014$)$ that it is not right that "hardworking taxpayers should pick up the bill for employment disputes in tribunals" and that "It is reasonable to expect people to pay towards the $f 74 \mathrm{~m}$ bill taxpayers' face for providing the service."

${ }^{11}$ Business Secretary Vince Cable spoke about "a widespread feeling it is too easy to make unmerited claims" (November 2011), <https://www.gov.uk/government/speeches/reforming-employment-relations >. Chancellor George Osborne, when announcing the increase in the qualifying period for claiming unfair dismissal from one to two years, stated "We respect the right of those who spent their whole lives building up a business, not to see that achievement destroyed by a vexatious appeal to an ET. So we are now going to make it much less risky for businesses to hire people."

$<$ http://www.conservatives.com/News/Speeches/2011/10/Osborne together we will ride out the storm.a spx>.

${ }^{12}$ Dickens, op. cit., n.3.

${ }^{13}$ The Employment Tribunals and the Employment Appeal Tribunal Fees Order 2013, No 1983.

${ }^{14}$ See the Legal Aid, Sentencing and Punishment of Offenders Act 2012.

${ }^{15}$ N. Busby et al., Citizens Advice Bureaux and Employment Disputes Interim Report (2013), at $<$ http://www.bristol.ac.uk/media-library/sites/law/migrated/documents/cabxinterim.pdf>.

${ }^{16}$ The Employment Tribunals Act 1996 (Composition) Order 2012.

${ }^{17}$ BIS, Payment of Tribunal Awards: 2013 Study (2013) at $<$ https://www.gov.uk/government/uploads/system/uploads/attachment data/file/253558/bis-13-1270enforcement-of-tribunal-awards.pdf>.

${ }^{18}$ The Employment Tribunals (Early Conciliation: Exemptions and Rules of Procedure) Regulations 2014. See also Acas, 'Early Conciliation: The Better Way to Resolve Workplace Disputes', at $<$ http://www.acas.org.uk/index.aspx?articleid=4028>.
} 
Acas (the Advisory, Conciliation and Arbitration Service) before initiating a claim in the ET. The aim of this is to try and facilitate an agreement between the employer and worker that represents a binding settlement, eliminating the need to go to the ET. Workers must notify Acas before submitting a claim to the ET. Acas will then appoint a Conciliation Officer to undertake conciliation between the parties, if they are willing. There is no obligation to do so. If either side declines, an EC certificate is issued which the claimant must present to the ET in order to lodge their case. EC remains an option for the parties at any stage before the ET hearing.

\section{Critique of changes to the ET system}

Labour law scholars and workers' rights advocates have responded strongly to these changes questioning the implications for workers seeking access to justice for employment disputes. Empirical data has been presented that demonstrates the negative impact of ET fees, deterring many workers, particularly those on low-incomes, from asserting their employment rights despite having potentially viable claims. ${ }^{19}$ This deterrent is compounded when workers take into account the persisting problems relating to the enforcement of ET awards. ${ }^{20}$ The difficulties workers experience when they cannot access adequate legal advice has also been demonstrated. ${ }^{21}$ With insufficient support, workers have difficulties identifying the legal basis for a claim, understanding how to proceed to submit a claim to the ET, how to prepare for the hearing, and how to act in the ET itself. The need for legal advice has also been identified for those who attempt to participate in Acas $\mathrm{EC}^{22}$ Moreover, it has been pointed out that the elimination of lay 'wing members' from unfair dismissal claims removes input from those with experience of issues faced by workers and employers, which may be outside of the realm of an employment judges' experience-potentially having negative implications for the fairness and perceived legitimacy of ET decisions. ${ }^{23}$

At a theoretical level, the recent changes made to the ET system have been framed as the continued pursuance of a neo-liberal policy agenda. Here we are referring to the generally accepted set of features of neo-liberalism, which include market fundamentalism, the prioritisation of competition (both in the market and between individuals), the maximisation of entrepreneurial freedoms, and an institutional framework characterised by private property rights. ${ }^{24}$ Bob Hepple observes that: "The [Coalition] Government is locked into a model where there is a presumption that regulation

\footnotetext{
${ }^{19}$ For example: Rose et al., op. cit. (2015a), n. 5; Rose et al., op. cit. (2015b), n. 5; E. Rose et al., Employment Tribunal Fees Deny Workers Access to Justice (Policy Briefing 6/2014), at <http://www.bristol.ac.uk/medialibrary/sites/policybristol/migrated/documents/employmenttribunalfees.pdf>.

${ }^{20}$ E. Rose et al., Enforcement of Employment Tribunal Awards (2014) at http://www.bristol.ac.uk/medialibrary/sites/law/documents/new-sites-publications/Enforcement\%20report final.pdf>.

${ }^{21}$ Busby et al., op. cit., n. 15; A. Pollert, 'The Unorganised Worker: The Decline in Collectivism and New Hurdles to Individual Employment Rights' (2005) 34 Industrial Law J. 3, 217; J. Holgate et al., 'Geographies of Isolation: How Workers (Don't) Access Support for Problems at Work' (2011) 43 Antipode 4, 1078; and C. Barnard and A. Ludlow, 'Enforcement of Employment Rights by EU-8 Migrant Workers in Employment Tribunals' (2016) 45 Industrial Law J. 1, 1.

${ }^{22}$ A. Sales et al., Citizens Advice Bureaux Clients and Advisers' Perceptions of Acas (2015) at $<$ http://www.bristol.ac.uk/medialibrary/sites/law/documents/ACAS\%20CAB\%20Report Final\%20\%281\%29.pdf>.

${ }^{23}$ D. Renton and A. Macey, Justice Deferred: A Critical Guide to the Coalition's Employment Tribunal Reforms (2013).

${ }^{24}$ See for example: D. Harvey, A Brief History of Neo-Liberalism (2005) and R. Plant, The Neo-liberal State (2010).
} 
interferes with the efficient working of free markets by limiting the employer's freedom to manage and hire and fire without restraint." 25 He identifies the dismantling of the tripartite structure of adjudication in the ET as a key example of neo-liberal philosophy "that regards the common law of contract and property as the natural basis of free markets and is hostile to state regulation which seeks to adjust conflicts of interest and conflicts of rights between workers and employers by the involvement of their representatives." 26

Similarly, Linda Dickens notes the way in which successive governments have positioned "'fairness' in opposition to 'efficiency"' and that 'efficiency' has been "narrowly defined as reflecting the interests articulated by some employer lobby groups." ${ }^{27}$ She identifies the Coalition government as exacerbating this trend towards market efficiency: "Social justice and moral arguments for employment rights tend to be muted currently and there is little emphasis on the responsibilities of business." ${ }^{28}$ Notably Dickens highlights how recent successive governments have framed the ET system as problematic. Reform agendas have focused on reducing the number of cases going to the ET and reducing the cost of the system-a far cry, she observes, from other potential goals such as giving substantive effect to individual rights and promoting fairer workplaces.

These analyses point to the conclusion that, when it comes to employment disputes, power has shifted towards employers and away from workers. The state has been instrumental in this process, equipping employers with more power-or perhaps more accurately, removing some of the power of workers -in terms of the regulatory and structural framework governing the resolution of workplace problems. But is this all that is going on? We suggest that a more nuanced account of the role of the state and the power relations they bring into effect is necessary. We articulate this by drawing on a specific understanding of neo-liberal governance as outlined below.

\section{APPROACH}

\section{Theoretical: A Foucauldian theory of power and neo-liberal governance}

The theoretical approach that we draw on in this article is based on Foucault's ideas about power and neo-liberal governance. These ideas describe a new way of thinking about power-framed as power relations because it is concerned not with power as exhibited by confrontation between adversaries but rather with how an individual or institution can act on or influence the actions of others. ${ }^{29}$ It examines the way in which individuals are turned into subjects, ${ }^{30}$ through which power can operate.

Foucault focused much of his attention on power relations as they operated between the state and the individuals over which it governs. We consider that the role of the state is critical in

\footnotetext{
${ }^{25}$ Hepple, op. cit., n. 3, 220.

${ }^{26}$ Id., 213.

${ }^{27}$ Dickens, op. cit., n. 3, 207.

${ }^{28}$ Dickens, op. cit., n. 3, 208.

${ }^{29}$ M. Foucault, 'The Subject and Power' (1982) 8 Critical Inquiry 777.

$30 \mathrm{Id}$.
} 
contemporary employment dispute resolution-due to the dominance of neo-liberal ideology and the, not unrelated, use of individual employment rights as the basis for the ET system. Despite this, the way in which the state exercises power relations is under-theorised and under-examined in labour law. As such, we suggest that Foucault's theoretical approach can usefully provide an explanatory factor not present in discussions about the ET system.

Foucault observed that in liberal societies the state structures its relationship with the population in such a way that it is able to shape the actions individuals' undertake. ${ }^{31}$ Power relations are not a mode of action that acts directly on a population, but rather "acts upon their actions" 32 How does it do this? Foucault observes of the state that "it incites, it induces, it seduces, it makes easier or more difficult; in the extreme it constrains or forbids absolutely." ${ }^{33}$ In essence, the exercise of power in this form consists in "guiding the possibility of conduct and putting in order the possible outcomes." ${ }^{34}$ This is achieved by transforming the rationalities and technologies utilised by the state in the exercise of political rule..$^{35}$

A key aspect of governance is that the state focuses its attention on individuals in a population, in contrast to the population as a whole, and conceives of these individuals as active agents who are free to choose and capable of rational decision making. Indeed, this freedom-or liberty-is critical to the exercise of power in this form of state governance. ${ }^{36}$ Dardot and Laval note: "To govern is not to govern against liberty or despite it; it is to govern though liberty-that is, to actively exploit the freedom allowed to individuals so that they end up conforming to certain norms of their own accord." 37 Individuals are not forced to do things or told they must act in a particular way. Rather, a perception of freedom of choice is created by the state. Options are available to individuals about how they live their lives and it is up to individuals to make decisions in this regard.

The strategies that the state employs to shape the actions of individuals are multiple. To some extent, the state simply needs to make some of the options available to people more or less attractive or more or less accessible. For example, it can be seen that the introduction of fees payable by workers seeking to assert their rights in the ET makes this option less accessible. There will be some workers who cannot easily afford these.

More fundamentally, though, the state seeks to create an alliance between individuals' personal goals and desires with state aims and objectives. States act to forge symmetry between the attempts of individuals to better their lives and the political values they are promoting. ${ }^{38}$ So, in terms of the state's goal of reducing the number of ET claims, the state would try and create an environment whereby individual workers themselves are of the view that going to the ET is an unappealing or inappropriate option. The hoped for result is that individual workers will make their

\footnotetext{
31 Id.

32 Id., 789.

33 Id., 789.

${ }^{34}$ Id., 789.

${ }^{35}$ N. Rose, Governing the Soul: The Shaping of the Private Self (1989), 5.

${ }^{36}$ Id.; Foucault, op. cit., n. 29.

37 P. Dardot and C. Laval, The New Way of the World: On Neo-Liberal Society (2013), 5.

${ }^{38}$ Rose, op. cit., n. 35.
} 
own choice not to assert their rights in the ET, which effectively mirrors the policy goals and agenda of the state.

States appeal to rationality to justify their particular aims and objectives. ${ }^{39}$ They actively produce and propagate 'regimes of truth', whereby ideas, such as the problem of high numbers of ET claims, become inscribed in institutions and other authorities, associated rules and procedures, as well as concepts and rhetoric that are circulated. ${ }^{40}$ Certain technologies can be utilised to enhance this process. These include the production of statistics about the rising number of ET claims over past decades and calculations regarding the costs associated with processing these. These 'truths' infiltrate society creating a particular perception of reality. Individuals are educated and solicited into accepting these truths. ${ }^{41}$ They increasingly become part of their value systems with which they seek to comply.

This process can be viewed as the shaping of the subjectivities of individuals who comprise a population. Nikolas Rose observes that "the regulatory apparatus of the modern state is not something imposed from outside upon individuals who have remained essentially untouched by it. Incorporating, shaping, channelling, and enhancing subjectivity have been intrinsic to the operations of government." 42 The goals of the state become ever closer to the goals that individuals in the population feel that emanate from within themselves. Individuals have the sense of choosing particular life practices out of a range of options. Yet, the reality and priorities upon which they base their decision making process are highly influenced by truths promoting in multiple ways and from multiple, decentralised sources. ${ }^{43}$

Contemporary neo-liberal governance exemplifies these relations of power between the state and the population. And this is the context in which recent changes to the ET system need to be viewed. In a neo-liberal state the overarching truth being propagated relates to the necessity of competition in society. ${ }^{44}$ Foucault notes that the role of the neo-liberal state is "to intervene on society so that competitive mechanisms can play a regulatory role at every moment." ${ }^{45}$ Workers, once viewed as in need of particular protections given their class disadvantages, are now reconceptualised as equally able to participate in the dynamic of competition and participate in an enterprise society. ${ }^{46}$ The neo-liberal state seeks to strengthen and propagate this truth to the point where the idea of generalised competition becomes both a self-evident truth and a behavioural norm. ${ }^{47}$

Ultimately, the subjectivity of individuals in a neo-liberal state is shaped in such a way as to bring about a new version of homo economicus who sees him or herself as an entrepreneur of themselves. ${ }^{48}$ This subject is free to choose how to live his or her life. However, as an enterprising

\footnotetext{
${ }^{39}$ M. Foucault, The Birth of Biopolitics: Lectures at the College de France 1978-1979 (2010).

40 Id.

${ }^{41}$ Rose, op. cit., n. 35.

42 Id., 213.

43 Id.; G. Turkel, 'Michel Foucault: Law, Power and Knowledge' (1990) 17 J. of Law and Society 2, 170.

${ }^{44}$ Foucault, op. cit., n. 39; Dardot and Laval, op. cit., n. 37.

${ }^{45}$ Foucault, op. cit., n. 39, 145.

$46 \mathrm{Id}$.

${ }^{47}$ Dardot and Laval, op. cit., n. 37.

${ }^{48}$ Foucault, op. cit., n. 39.
} 
subject, they are obliged to choose action that maximises their own economic self-interest. ${ }^{49}$ The individual thus becomes governable. The state can understand workers' behaviour as economic behaviour and can attempt to influence this by modifying the variables of the environment knowing that the individual will respond based on rational economic justifications. ${ }^{50}$ Viewed in this light, the state can implement changes to the ET system which will be interpreted and acted upon by workers using an economic rationality.

\section{Methodological: Our empirical dataset}

The data presented in this article is drawn from an European Research Council funded project entitled Citizens Advice Bureaux and Employment Disputes. The overall aim was to understand workers' experiences as they attempted to resolve problems faced at work, including identifying potential barriers to justice. We focused on workers who could not easily afford the services of a solicitor. As such, participants were recruited through Citizens Advice Bureaux (CABx) who are a key provider of employment advice to this group. ${ }^{51}$ Data collection was undertaken during the period July 2011 to December 2014.

The primary methodology employed involved the 'tracking' of workers who became clients of $\mathrm{CABx}$ - from their initial interaction with the bureau through the process of their working their way through their employment dispute or otherwise abandoning it. This meant that we were able to gather data on the thoughts, feelings and actions of workers from the early stages of their dispute throughout the course of receiving advice of the dispute and taking action (or not) in relation to their dispute.

Information was collected from 158 workers from seven bureaux throughout England (3), Scotland (3) and Northern Ireland (1). Data sources included observation of advice appointments between $C A B x$ advisers and their clients, ongoing interaction with bureaux clients during the course of their dispute through various mediums, observation of ET hearings, and final face-to-face interviews with bureaux participants. Detailed notes were taken of all encounters with worker participants. Audio recording was undertaken wherever possible and in all final face-to-face interviews. All audio recordings were fully transcribed.

Out of the 158 workers participants, 58 submitted a claim to the ET (or Industrial Tribunal as it is called in Northern Ireland) (38\% of known cases), 2 pursued their claim in the (English) County Court or (Scottish) Sheriff Court, and in 5 cases we were not able to establish whether a legal claim was lodged or not (largely due to losing contact with the worker participant). Refer to Table 1 below.

\footnotetext{
${ }^{49}$ Id.

$50 \mathrm{Id}$.

${ }^{51}$ B. Abbott, 'The Emergence of a New Industrial Relations Actor-The Role of Citizens Advice Bureaux?', (1998) 29 Industrial Law J. 4, 257.
} 
Table 1: Participants and legal action taken by bureaux

\begin{tabular}{|l|l|l|l|l|l|}
\hline Bureaux & $\begin{array}{l}\text { Number of } \\
\text { worker } \\
\text { participants }\end{array}$ & ET claim lodged & $\begin{array}{l}\text { County or } \\
\text { Sheriff Court } \\
\text { claim lodged }\end{array}$ & $\begin{array}{l}\text { No legal } \\
\text { claim made }\end{array}$ & $\begin{array}{l}\text { Unknown if } \\
\text { legal claim } \\
\text { made }\end{array}$ \\
\hline A & 22 & 7 & 0 & 14 & 1 \\
\hline B & 34 & 20 & 1 & 12 & 1 \\
\hline C & 3 & 1 & 0 & 2 & 0 \\
\hline D & 31 & 7 & 0 & 22 & 2 \\
\hline E & 22 & 7 & 0 & 15 & 0 \\
\hline F & 23 & 10 & 0 & 13 & 0 \\
\hline G & 23 & 6 & 1 & 15 & 1 \\
\hline Totals & 158 & 58 & 2 & 93 & 5 \\
\hline & & & & & \\
\hline
\end{tabular}

In addition to gathering data from workers experiencing disputes, we gathered information from advisers and managers of CABx. This involved semi-structured interviews, participant observation and ongoing informal interaction with advisers and managers from the 7 participating bureaux. All interviews were audio recorded and fully transcribed.

Additional information was obtained through a subproject undertaken collaboratively with Citizens Advice Scotland which focused specifically on the impact of ET fees. This work comprised two components. Firstly an online survey was made available during April 2014 to all known CABx advisers in Scotland who provide employment advice (a population of 27). ${ }^{52}$ Fourteen surveys were completed. Secondly, two focus groups, comprising 13 advisers, were undertaken on 15 August $2014 .^{53}$ One additional face-to-face interview was conducted approximately one week later with an adviser who was unable to attend the focus groups. Both the focus groups and the additional interview were audio recorded and fully transcribed. Although this subproject was particularly enlightening as to the impact of fees, the majority of data collected from the main study pre-dated in the introduction of fees. For this reason, any reference to fees in the following analysis is based either on general observations outside of the data set as well as the views and perceptions of the advisers interviewed in the subproject.

\section{FINDINGS AND ANALYSIS}

This section is divided into four parts. Firstly, we describe the context in which the recent changes to the ET system have been made-specifically, we consider the 'truths' presented by the neo-liberal state as expressed in moral codes and embedded in institutional context and processes. This demonstrates the very active and ongoing role of the state in relation to the power dynamic at play in employment disputes. Secondly, we show how these 'truths' have shaped workers subjectivities to the extent which they influence their decision making about what to do when faced with an employment dispute. Thirdly, we demonstrate how this shaping of worker subjectivities extends to a particular moral view regarding the assertion of individual employment rights. These second and third parts of this section shows how the actions of the state shape more than the objective context that workers find themselves in when experiencing an employment dispute, but also, critically,

\footnotetext{
${ }^{52}$ For further details refer to: Rose et al, op. cit. (2015b), n.5.

53 Id.
} 
workers' subjective moral codes about appropriate courses of action to take. Fourthly, and finally, we show that despite this shaping of worker subjectivities being powerful, it is not exhaustive or complete. Workers continue to hold non-economic values and these can clash with solely economic concerns.

\section{'Truths' as expressed in moral codes and embedded in institutional contexts and processes}

A key 'truth' justifying the recent changes to procedural aspects of the ET system has been the stated problem of high levels of claims being made to the ET. The actions of workers who make claims in the ET have identified as being problematic. Statistics have been produced evidencing the rise in numbers of claims over time..$^{54}$ The category of difficult workers is growing. There is a notable lack of acknowledgement that workers may be making claims because of continued problems in the relationship between employers and workers. ${ }^{55}$ Further description (and discrediting) of the group has been provided by suggestions that many who go to the ET have vexatious and frivolous claims. ${ }^{56}$ This is framed as particularly problematic because these workers are acting as a "brake on business. ${ }^{57}$ In addition, these problematic ET claimants are costing the taxpayer a great deal of money. ${ }^{58}$ It is not fair that public monies are spent supporting the ET system for the benefit of this problematic group of workers. The general message is that ET claimants are morally reprehensible individuals causing problems to society in economic terms and the state needs to do something in order to reduce the number in this group.

These claims gain weight when considered in the broader context of political priorities and rhetoric. The government has argued that the global recession and general instability of financial markets necessitate the need for austerity measures. ${ }^{59}$ Public expenditure must be cut. This is the most rational and morally appropriate state response as it will bring about longer-term economic growth in the country. Workers - 'strivers' - must be celebrated as they contribute to the economy, whilst those not in paid employment-'skivers'-are demonised. ${ }^{60} \mathrm{~A}$ moral value becomes attributed to those who contribute to the economy. Workers are held in esteem, whilst those who fall outside of this and are not economically active are of less or even no value. Entrepreneurs hold a special place in this hierarchy of social importance. This can be seen by the way that entrepreneurial needs are

\footnotetext{
${ }^{54}$ Refer Coalition government assertions regarding claims rising to record levels, at <https://www.gov.uk/government/news/employment-tribunal-fees-to-benefit-business-and-taxpayers>. This contrasts with official statistics reporting a reduction in claims, Annual Tribunals Statistics, 1 April 2010 to 31 March 2011, (MoJ/HMCTS, 2011), 5.

55 D. Renton, Struck Out: Why Employment Tribunals Fail Workers and What Can Be Done (2012).

${ }^{56}$ See N. Busby and M. McDermont 'Access to Justice in the Employment Tribunal: Private Disputes or Public Concerns?' in Access to Justice: Beyond the Policies and Politics of Austerity, eds. E. Palmer et al., (2016).

57 Dickens, op. cit., n. 3.

58 Op. cit., n. 10 and 11.

${ }^{59}$ See George Osborne's emergency budget statement 2010:

<http://www.telegraph.co.uk/finance/budget/7846849/Budget-2010-Full-text-ofGeorge-Osbornesstatement.html>.

${ }^{60}$ Z. Williams, 'Skivers v Strivers: The Argument that Pollutes People's Minds' The Guardian, Wednesday 9 January 2013, at <http://www.theguardian.com/politics/2013/jan/09/skivers-v-strivers-argument-pollutes>.
} 
deemed appropriate policy drivers. The 'Red Tape Challenge' focusing on employment law ${ }^{61}$ provides an example of this. Moreover, workers who interfere with an entrepreneur's managerial prerogative by raising disputes are assumed to be doing so for unmeritorious or vexatious reasons. ${ }^{62}$

These truths and moral codes have been embedded into a range of state institutional contexts and processes. So, directly relating to the ET system, there is the introduction of ET fees which have been attributed with causing a nearly $70 \%$ reduction in claims across all jurisdictions following their introduction. ${ }^{63}$ Fees represent the practical implication of the statement that it is only reasonable to expect users of the system - which operates at great cost to taxpayers - to bear some of the cost of this. ${ }^{64}$ There is the elimination of legal aid for employment disputes in England and Wales. Such financial support is problematic because it is very costly to taxpayers, but also unfair to those who do not benefit from the provision of legal aid. The introduction of compulsory EC through Acas is characterised as a positive option because it is less costly for individuals and the state. ${ }^{65}$ The speed of EC is also promoted as a benefit for business because, presumably, long drawn out disputes may inhibit their primary goals of profit generation. No mention is made of the fact that EC does not result in a legal judgement of right and wrong regarding employment rights but rather facilitates a mutual agreement between the parties involved. ${ }^{66}$

Now, when faced with a workplace problem, workers must make decisions about how to pursue their claim (or not) in the ET system. While they must now register for EC, workers can choose whether or not to engage with it. If not, there is the decision to go to the ET, which means deciding on the steps of paying the issue fee and the hearing fee. And, if a worker's case is successful and they are granted an award which is then not paid (the chances of which are quite likely), there is the decision about whether or not to pay further monies to take formal action to enforce the award. Dardot and Laval describe this form of state governance, involving multiple choices, as follows:

It is therefore no longer a question, as it was in welfarism, of redistributing goods in accordance with a certain regime of universal rights to life ... but of appealing to the calculating capacity of subjects to make choices and achieve results ... This presupposes

\footnotetext{
61 'The Red Tape Challenge: Employment Law' at <http://webarchive.nationalarchives.gov.uk/20150522175321/http://www.redtapechallenge.cabinetoffice.go v.uk/themehome/employment-related-law/>

${ }^{62}$ Express statements to this effect have been made by key Coalition Government Ministers, including Business Secretary Vince Cable's speech to the Engineering Employers' Federation (November 2011), refer <http://www.gov.uk/government/speeches/reforming-employment-relations>. Likewise, Chancellor George Osborne made similar comments when announcing the increase in the qualifying period for claiming unfair dismissal from one to two years, refer $<$ http://www.conservatives.com/News/Speeches/2011/10/Osborne together we will_ride_out the storm.a spx>.

${ }^{63}$ See the House of Commons Justice Committee Report (2016), HC 167, available: <https://www.publications.parliament.uk/pa/cm201617/cmselect/cmjust/167/167.pdf>.

${ }^{64}$ See Ministry of Justice (2017) 'Review of the Introduction of Fees in the Employment Tribunal' at <https://www.gov.uk/government/uploads/system/uploads/attachment data/file/587649/Review-ofintroduction-of-fees-in-employment-tribunals.pdf>. At 5 it states that the Government's 'financial objective' has been met as "those who use the ETs are contributing around $f 9$ million per annum in fees ... transferring a proportion of the cost of the ETs from taxpayers to those who use the Employment Tribunals."

${ }^{65}$ Acas provides information, advice, training, conciliation and other services for employers and employees aimed at preventing or resolving workplace problems.

${ }^{66}$ Foucault, op. cit., n. 29.
} 
that, to be 'responsible', subjects possess the data for this calculation, comparative indicators, quantitative expressions of their activity, or, more radically, of the monetization of their 'choices'. ${ }^{67}$

In essence, the state has brought about a situation in which workers have an obligation to choose which path to take and, importantly, the options available each come with varying degree of risk and moral value.

For those who find themselves in a workplace dispute, losing their job and being out of work is likely not far from their mind. However, the state and its institutions actively engage in the ongoing vilification of those not engaged in paid employment. This can be seen in the treatment of those in receipt of the Job Seekers Allowance. They are disciplined by an aggressive system of obligations imposed on them, such as the need to apply for a certain number of jobs in set periods. Perceived infringement of these obligations can result in the sanctioning of benefits, which can have extremely negative effects on that person's ability to meet their basic needs and their mental wellbeing. ${ }^{68}$ These practices, though, inculcate a sense of having to earn the right to receive government assistance. This contrasts with other visions of the role of the state which may encompass the idea that the state has a responsibility towards those in need.

For those individuals who are in work, particularly at the lower end of the labour market, there has been a downward shift in the degree to which they should expect quality work conditions. A key way in which this message has been conveyed is by the proliferation of jobs offered as non-standard forms of employment. The state, through its lack of decisive action on the issue, is effectively condoning these practices that reduce the costs associated with standard employment contracts. The effect is to normalize the idea that workers should bear some of the risk of business on behalf of their employers. This is legitimised by the promotion of an entrepreneurial rationality that attributes to all individuals the same goals of economic maximisation.

It is clear that the state is very active in shaping the contextual tone in which those who experience a workplace problem find themselves. Certain values are promoted, with others minimised, ignored or actively denounced. These acts of the state are over and above the setting of a regulatory and structural framework by which employment disputes are resolved. Indeed, aspects of the regulatory and structural framework that is set are, far from being neutral, actively imbued with, or perhaps tainted by, particular qualities, values and connotations by the state.

\section{Workers' obligation to choose in accordance with homo economicus}

Our findings reveal the ways in which the neo-liberal 'truths' relating to the ET system and its broader context have, to some extent, been internalised by workers, shaping their subjectivities about what they perceive to be morally appropriate behaviour. Once they received legal advice regarding their workplace problem, our participants had to make decision regarding whether or not to pursue their dispute in the ET and, if so, which steps to take. To a large extent these decisions

\footnotetext{
${ }^{67}$ Dardot and Laval, op. cit., n. 37, 180.

${ }^{68}$ Citizens Advice Scotland, Sanctioned: What Benefit? (2014) at <http://www.cas.org.uk/system/files/publications/Sanctioned\%20What\%20benefit.pdf>; D. Webster, 'Jobseeker's Allowance Sanctions and Disallowances' Working Brief 2013, 233: 6-7.
} 
were guided by reasoning involving economic rationality and the management of risk ${ }^{69}$-key principles of the neo-liberal orthodoxy. However, importantly, the participants viewed their decisions as coming from themselves.

At one level, some participants expressed an unquestioned acceptance of the 'truths' presented by the state. For example, one participant commented on ET fees: "Up front, it is a lot of money if somebody's been sacked or whatever ... But you can understand if there's 100 people claiming a tribunal and say there's only $25 \%$ legit or even $50 \%$ are legit the other $50 \%$ are wasting their time ..." (Ray)..$^{70}$

More notable, though, was the way that participants' decision-making process typically involved a weighing up of the financial costs of a particular course of action against the risks involved, notably the likelihood of success of a particular course of action. Economically sensible decisions predominated. This can be seen in the case of Laura.

Laura worked for a large supermarket chain for more than six years. One day the store security guard filmed her on CCTV when she was going to her car during a break. He claimed she was taking illegal drugs. Laura denied this stating that she was simply taking hay-fever remedy. Laura was suspended from her job. Laura offered to have a drug test taken immediately (it was still within the appropriate timeframe for a valid test). However, the employer declined to do so. Laura had her own test taken, which showed that she had not been under the influence of illegal drugs. Laura attended a disciplinary meeting. In this she tried to show her drug test results. Her manager informed her that they did not need any further proof as their evidence showed beyond reasonable doubt that she was taking illegal drugs. Laura was dismissed. A CAB adviser informed her that she would have to pay a total of $£ 1,200$ to take a claim to the ET for unfair dismissal. Laura decided not to pursue her claim.

Laura had initially felt very positive about her claim for unfair dismissal. However, after finding out about the cost she would need to incur to pursue this in the ET decided that she simply could not take the risk expending this amount of money. She stated:

At the end of the day ... I could've won and I might not have done. I haven't got $£ 1,100$ [sic] to pay on something I might not win. ...I'm on my own with two children without a job at the moment ... If I knew I could claim my money back ... even if I lost, at least I've got that money back, I would've been okay ... But I can't afford to pay over $£ 1,000$ for something which is a gamble. I might as well just go to the bookies.

The outcome was devastating for Laura. She felt very aggrieved at the situation. But she knew she was ultimately responsible for herself and her children and to spend the amount of money required to pursue the claim was simply too risky.

Other participants chose to accept a settlement offer from the employer despite this being for an amount lower, sometimes substantially so, than what the ET would likely award. A key factor

\footnotetext{
${ }^{69}$ The notion of workers being economically rational and risk adverse has been recognised historically within labour law, see for example H. Sinzheimer, Foundations of Labour Law.

${ }^{70}$ All participant names given are pseudonyms.
} 
contributing to this decision was the notion that this course of action was less risky. This even occurred prior to the introduction of ET fees, as was the case with Jimmy.

Jimmy worked as a landscape gardener for a small employer. The job had been advertised as paying the national minimum wage. However, details of when and how he would be paid were not provided. After several months' work, Jimmy received a payment of $£ 2,000$ but this was unaccompanied by any kind of wage slip or breakdown of the amounts. Jimmy attempted to pursue this with his employer who was very evasive. Eventually, the employer discontinued offering work. Jimmy went to the $C A B$ to get information about whether his responsibilities regarding income tax and national insurance. The bureau solicitor informed Jimmy that he had a potential claim for unpaid wages that totalled more than $\mp 1,000$. Jimmy lodged an ET1 form ${ }^{71}$ with the ET. Prior to the hearing Jimmy accepted a settlement of around $£ 500$.

Jimmy decided to settle for a lesser amount than what he was claiming in the ET because he thought it was probably the best he would get from the situation. He reasoned that the outcome of going to the ET was very uncertain. He could not be sure that he would be awarded the amount he was claiming or that the employer would actually pay any award. As such, Jimmy thought the best option was to accept what the employer was offering.

These workers are demonstrating a decision making process whereby economic rationality predominates. It does so to a greater extent than other possible criteria, such as strength of one's claim. The reasoning of these workers is not isolated, particularly in the post-ET fees environment. One adviser from a CAB in Scotland observed: "It's amazing the number of people now willing to compromise their claims if they get even a half decent offer you know from the other side through the Acas process rather than face the risk of actually going to hearings and not getting money" (Focus group participant). The risk factors that workers considered were many and included the ET fees, the fees required to enforce any award that was unpaid, and the degree of legal support the worker could access that would help contribute to their chances of success.

Conceptions of risk extended beyond the immediate process of engaging with the ET system to the broader issue of re-entering or ensuring continued participation in the paid labour market. Experiencing an employment dispute that was potentially a legal claim typically results in the worker leaving that position some way or other. Trying to find another job after leaving one due to a dispute can be problematic; a worker typically needs to have their side of the dispute vindicated by the ET or be in receipt of a satisfactory reference from the employer with whom they had the dispute. Our findings demonstrate that ensuring that one had a clear record as a 'good worker' was a key driver in the decision making process, as exemplified by Sally.

Sally worked part-time in a customer service role in a large retail company. Her employer wanted to make her hours more flexible. They informed her that she needed to be available for any shift during the week or else her contract would be terminated. Sally agreed, but stated that she could not do Friday evenings as she assisted with a charity group and Saturday afternoons when her husband

\footnotetext{
${ }^{71}$ The form required to submit a claim in the ET.
} 
coached a youth football team. Subsequently, Sally was called in for a 'quiet meeting' with Human Resources. They accused her of misleading them about her circumstances, stating that her husband wasn't actually working on the Saturday afternoons-he was only volunteering. Sally was told this amounted to gross misconduct and she was dismissed. Sally was very upset. She attended her local CAB where an adviser helped her lodge an application to the ET. (Sally's case arose prior to fees being introduced). In the end, though, Sally didn't go to the tribunal. Instead she reached a settlement via Acas, which included a reference and a financial sum.

The key reason that Sally settled was so she could get a reasonable reference from her former employer and obtain another job. The need for a reference became abundantly clear to Sally during the course of her dispute. After her dismissal, Sally was offered a paid job managing a charity shop. However, the offer was conditional upon the reference. The charity made contact with Sally's former employer and subsequently withdrew their job offer to Sally. Sally was subsequently offered another position, again subject to receipt of a satisfactory reference. The offer stood the day before the ET hearing and Sally wrestled with her competing desires to have her case heard and to obtain a satisfactory reference.

It was the day before the tribunal went ahead. And I was so close to "no I'm not acceptin' it [the settlement]". ... And then I thought "well I'm waitin' on a reference so I can start this job I'm in just now" and I thought "I'll just accept it 'cause then I've got me job."

Sally and her husband, who received a sickness benefit, had been struggling financially and could not risk losing another offer of employment. They felt that it would be foolish not to accept the settlement. Despite a desire to have her case heard in the ET, Sally made an economically rational decision to accept a settlement which ensured that she could participate again in the paid labour market.

What we are seeing here, then, is the effect of the state's governance in which it acts upon the actions of workers. ${ }^{72}$ The state is achieving a degree of success in guiding the actions of workers away from attempting to assert their employment rights in the ET. The option of doing this is made less attractive by the monetary costs of doing so and the level of risk of achieving a good outcome through this route. It is not simply the objective constraints that are operating here. It is also the shaping of worker subjectivities to promote market values. This takes form in the way that workers decision making is based largely on an economic rationality, which assumes individual responsibility for decisions and requires workers to factor in chances of success against the potential risk, including the issues that may arise in relation to the workers' ability to remain in the labour market.

\section{The morality of asserting employment rights}

The shaping of worker subjectivities was also demonstrated by some participants in the way that they appeared to have internalised a deep concern about the legitimacy and appropriateness of challenging employers and pursuing their employment rights. This manifested as a sense of shame or embarrassment for experiencing conflict with one's employer or asserting one's rights against an employer. To some degree, these participants almost perceived it to be expected of them that they,

\footnotetext{
${ }^{72}$ Foucault, op. cit., n. 29.
} 
as workers, should be responsible for ensuring a satisfactory relationship between employer and themselves. This perhaps is plausible in an environment where workers are attributed with similar goals as employers or entrepreneurs, i.e. that of economic success.

Sally, the participant described above who was hoping to claim unfair dismissal in the ET but instead accepted a settlement, felt a sense of shame about having a problem at work and losing her job. She described how she became virtually house-bound during the course of her dispute. This impacted on her day-to-day interactions with others in her community.

I kinda became a hermit for a long time, there was two weeks that I wasn't goin' out ... I couldn't even go and get [daughter] from school because there was so many people at the school who knew where I worked and, it was horrible ... Just buried my head in the sand.

On the one hand, Sally did consider that she had been treated terribly by her employer. But this did not overcome the sense of disesteem or stigma that she also carried. She had gone from a person who was in the paid labour market to someone who had a dispute at work, was dismissed and now had a tainted employment record. In many ways, she was placed at the constitutive limit of what has been labelled as valuable by the neo-liberal state. ${ }^{73}$ This is not a position that engenders pride or confidence in oneself.

Another example can be seen in the case of Cheryl.

Cheryl, a 21 year old woman, worked in her first paid role as an early education and childcare officer. After some difficulties at work she decided to leave the job and handed in her notice. Her employment contract didn't appear clear as to the notice period required. Cheryl looked online to check statutory notice periods and considered this to be one week. Cheryl's manager agreed that the contract was vague but that one week's notice would be fine. By this point Cheryl had arranged to start a new job. Subsequently the owner of the company told Cheryl that she needed work out four weeks' notice and that if she didn't do this she would not be paid her last pay packet which included three of four weeks' pay for hours she had done. Cheryl sought advice from the CAB. They assisted her to lodge an ET1 form for unpaid wages. (This was done prior to the introduction of ET fees). Cheryl won her case and was granted an award to the sum of the withheld wages.

While Cheryl was ultimately successful in her claim, she did not find the experience easy or comfortable. She noted:

Actually, I didn't tell all that many people. I was actually quite embarrassed that I had to take my first employer to court ... so the only people I told were really close friends and family, and even then, I didn't say too much. People who knew about it just asked how I got on. And [I] text to just say I won my case. I will get my money. I was quite ecstatic about it, but it wasn't something that I wanted to put out there. [Be]Cause I think people often assume there's something worse to the case when you say the tribunal court. They think: your first employer, that's a bit much!

Cheryl anticipated negative reactions to what she was doing-even from people who knew her. Cheryl perceived there to be a lack of solidarity amongst those in her social circle regarding her

${ }^{73}$ B. Skeggs, 'Value Beyond Value? Is Anything Beyond the Logic of Capital' (2014) 65 Brit. J. of Sociology 1. 
experience. This is despite her being at the receiving end of illegal practice from her employer, which was confirmed in the judgement given by the ET.

State institutions were complicit in perpetuating, or at the very least failing to counter, the idea that workers are responsible for maintaining good relations with employers-even when employers are clearly acting in bad faith. Doug's situation provides an example.

Doug worked in a seasonal position as a gardener for the local council. During the off-season he went to the Job Centre to try and find alternative employment. Doug took on a position as a cavity wall insulator, which was advertised as a 40 hour per week role paying the national minimum wage. Doug worked for about a month but was not paid any wages. The employer periodically told Doug that he was not needed for a few days and that Doug should sign up for benefits. The employer subsequently went into liquidation. Doug was owed wages but could not make a claim as the employing entity no longer existed.

Doug was very aggrieved by his situation, particularly because he felt that the Job Centre (together with the Department of Work and Pensions) had forced him to take this job. He would not be allowed to claim benefits if he refused to take on the position. Doug complained to the Job Centre but was told "'that's between you and the employer it's nothing to do with us,"' on which he reflected: "basically... I felt they couldnae care less."

These findings suggest that challenging one's employer and asserting one's employment rights goes against cultural norms about what is appropriate and valued behaviour. ${ }^{74}$ This appears to be strongly shaped by the neo-liberal 'truths' and values promoted by the state. Interestingly, though, the notion of employment rights per se did not appear to be viewed negatively, at least from our data. When a worker is in employment and is a valued member of society contributing to the economy they are deserving of fair treatment within the law. But it seems that the acts of claiming a breach of these rights and attempting to assert them are rather more highly charged. Clearly there is a risk in viewing rights as simply protective or emancipatory. Rather, their utility needs to be considered in light of the actual context-including power relations-in which workers may seek to assert them. ${ }^{75}$

\section{The persistence of values beyond the neo-liberal frame}

But, our data reveals that this sense of employment rights or, perhaps more specifically, the sense of what is right regarding employment, is very conflicted. Indeed, many study participants demonstrated a strong clash of values between those promoted by the neo-liberal state and those that they continue to hold that fall outside of the economic frame. A number of participants expressed disbelief, anger or upset when they found out the realities of the ET system. This occurred, for example, if they found that they were priced out of pursuing their claim in the manner that they wanted, that they viewed their chances of success too low for them to attempt to assert

\footnotetext{
${ }^{74}$ For another example, see D.M. Engel, 'The Oven Birds Song: Insiders, Outsiders, and Personal Injuries in an American Community' (1984) Law \& Society Rev. 18, 4.

75 Drawing on B. Golder, Foucault and the Politics of Rights (2015).
} 
their rights-regardless of the merits of their claim, or that they had breached some timeframe within which they were allowed to pursue the claim. The participants could perhaps accept this information if they relied solely on reasoning that was economically rational and accepted the idea that all individuals are responsible for themselves. However, this was not the case. The participants held non-economic values that stemmed in large part from ideas about the appropriate relationship being one of mutuality between employer and worker.

This clash of values can be seen particularly when workers describe their motivations for pursuing the claim, as if the participants are justifying actions that do not easily fit with explanations based on economically rational grounds. The participants may be attempting to assert their rights in circumstances where their particular claim is difficult to prove or where they were offered a less risky financial settlement. The reasoning drawn on extends beyond economic considerations. Frank provides an example of this.

Frank worked as a charge-hand in a bar for 13 years. He took one week's leave from his job. When he returned there was a dispute regarding the exact date that he should have recommenced work. Frank's manager swore at him and called him names. Frank remembers her telling him "You're finished here." The manager was angry and Frank was afraid she was going to hit him. Frank worked the rest of his shift. However, the next day he handed in his keys and said he would not be back. Frank felt that the manager was a bully, that he had been treated unfairly, and that he should, at a minimum, be owed his outstanding holiday pay. Frank went to his local CAB for advice. The solicitor there said it was not completely clear whether he had resigned or was fired. The solicitor told Frank that he may have a claim for unfair dismissal, but this may be difficult to prove as there was nothing in writing and no witnesses to the events and, because of this, the hearing could simply turn on whose word is to be believed.

Despite the potential difficulty in proving his claim, Frank was adamant that he wanted to pursue a tribunal application. (The dispute took place prior to the introduction of ET fees). Frank said his motivation for doing this was not just the money, but because he wanted "the truth to come out": "It was basically to let people know how I got treated, if I got like a payment it would have been a bonus but basically to let people know how I got treated." Frank felt hurt and disrespected by his employer and he wanted to remedy this situation. ${ }^{76}$

Mike, a 29 year old man who had worked in a convenience and liquor outlet store for eight years, provides another example.

Mike's role was assistant manager and as part of this he had to prepare the staff rotas each week. One day his manager informed him that the rotas were not useful and that they needed to be fixed. The manager failed to clarify what was wrong with them and sent Mike home. Mike subsequently received a text message from the owner of the business telling him to attend a disciplinary meeting for his refusal to obey orders and for a cash shortage issue. In the disciplinary meeting it emerged that the rota problem related to not ensuring an appropriately licensed person was on duty in the

\footnotetext{
${ }^{76}$ For further discussion, see L. Barmes, Bullying and Behavioural Conflict at Work: The Duality of Individual Rights (2016).
} 
store at all times to satisfy the requirements of their off-sales license. However, it had been standard procedure in the shop, including by the manager, to operate in this way. Mike was dismissed. Mike sought advice from the CAB. The bureau solicitor helped Mike lodge an ET1 form claiming unfair dismissal and seeking an award of approximately $£ 8,000$. (The dispute arose prior to the introduction of ET fees). A few days before the hearing the employer made an offer of $f 500$. Mike rejected this. He went to the ET and was awarded approximately $£ 15,000$.

Mike had been keen from the outset to take legal action because he felt that his employer had treated him badly. After he had been dismissed he struggled to find another job and was feeling the financial repercussions of this. However, Mike claimed that taking the employer to the ET "wasn't about the money, it was about proving, proving the fact is they [the owner and manager] were wrong." When he received the offer from the employer, which was substantially lower than what was claimed, Mike rejected this outright. Even if more money had been offered, Mike indicated that he would be torn between taking it and going to the tribunal.

I would have [accepted] if they like they offered the eight thousand that we calculated, if they offered me that l'd have felt cheated in a way because they've just paid me off if you want to put it and l've not had my day in the tribunal where l'd rather have my day in tribunal and forget the eight thousand pound because l'd be happy the fact that I've showed somebody that I was, they were wrong and I was right so I'd have been mair happy at that."

Mike viewed it to be important to be able to make his point about right and wrong to the employer. This was a powerful driver that was more attractive than being "paid off".

This objection to purely financial settlements to employment disputes was reiterated by a solicitor at a CAB. She observed that many of her clients were not completely comfortable by their perceived focus of Acas of basing the resolution of a dispute purely in monetary terms.

I know a lot of clients come back to me and say that they're [Acas] sometimes not very helpful or even, as one client recently said, she was quite rude because this client was saying "no, I don't want that." It's almost like they expect you to just say, "yes, I'll settle for that amount of money," and because [the client] said no, [xx] is what she wants, [the Acas conciliator] was quite rude and put her off a bit. I think sometimes [the Acas conciliators'] think, oh, it's just about the money, where it's not necessarily just about the money, is it? (Solicitor, Bureau D)

It is acknowledged that Acas' involvement in individual dispute resolution takes many forms and can take place at several different stages. Moreover, study participants' perceptions of Acas were generally positive, especially in relation to the Acas website and telephone Helpline. However, the negative experience reported here is reflective of a wider dissatisfaction among the participants in relation to the limited outcomes available through conciliation which is generally confined to financial settlement. Part of the unease is because Acas settlements do not provide a judgement about the merits of a case. Rather, they seem to implicitly assume that there is culpability or blame on both sides that can be neutralised by striking a compromise. Moreover, many settlements include a confidentiality agreement that prevents the worker from even talking about the details of the settlement, further reducing the ability of a worker to demonstrate-to themselves and others - that their side of the dispute has merit. 
Many of our participants held views on the appropriate forms of relations between themselves, as workers, and their employers. These included notions of respect, and loyalty, which resonate somewhat with the implied common law term of mutual trust and confidence which is read into every contract of employment. ${ }^{77}$ This imposes a duty on each party that it will not "without reasonable and proper cause, conduct itself in a manner likely to destroy or seriously damage the relationship of confidence and trust between employer and employee" 78 The duty is reflective of the expectations that workers have about appropriate treatment by their employer. This is demonstrated by the example of Heather and Mary.

Heather (55 years) and Mary (73 years) had worked as cleaners for a facilities management company for 8 and 10 years respectively. They worked for six hours each week at two branches of a bank and were paid the minimum wage. Heather and Mary took a short period of sick leave when Heather's father/Mary's husband passed away. During this time the employer hired a replacement to work in the bank branches. When Heather and Mary returned to work they were only offered reduced hours at locations further away, which were unworkably costly to travel to. Heather and Mary sought advice from the CAB. The solicitor there informed them that their options may be limited because, according to their contract, the employer could make changes to their hours of work. The solicitor suggested that the women send a grievance letter to their employer and, if the employer ignored this, they could make a claim in the ET for constructive dismissal. However, the introduction of ET fees was pending. Heather and Mary did not lodge an ET1 form before they were introduced and then felt that it was too expensive to pursue their claim.

Heather felt angry about what had happened to her and her mother. She considered that they had been treated as simply replaceable, which was not appropriate given that Heather and Many had been loyal workers who took care in their job.

When I start to talk about it, ye know, I get myself intae a state because I think "how can they treat people like that?" After, eight years I was there, going on nine years, my mum was there for ten, so why treat us like that ... Never a complaint against ye or anythin'. Why did they do that to us?

Heather spoke a lot about the lack of respect and the lack of reciprocity of goodwill from the employer compared with that given by Heather and Mary. The sense of relations between worker and employer was particularly complex given Heather and Mary's rapport with the bank staff, who appeared as if the people for whom Heather and Mary worked but, technically, were not. Heather stated: "It's just a shame because I loved that bank, the bank staff were just brilliant. They kept sayin' we were just a wee family, y'know, they're no' wur cleaners, they're part of our family."

In effect, the efforts of the state to guide workers in the decisions they make about the ET process only address issues in economic terms. Foucault observed that the neo-liberal state considers the individual only as homo economicus, but of course individuals are always more than this. ${ }^{79}$ Economic

\footnotetext{
${ }^{77}$ Refer D. Brodie, 'How Relational is the Employment Contract' (2011) 40 Industrial Law J. 3, 232.

${ }^{78}$ Courtaulds Northern Textiles Limited v Andrew [1979] IRLR 84; Woods v WM Car Services

(Peterborough) [1981] ICR 666.

${ }^{79}$ Foucault, op. cit., n. 39; Skeggs, op. cit., n. 73.
} 
behaviour is the grid of intelligibility held and utilised by the state. ${ }^{80}$ But the participants in our study clearly demonstrated other, non-economic, values and, at times, these come to the fore and were prioritised over economic values.

\section{DISCUSSION AND CONCLUSION}

In this paper we have reconceptualised power relations in employment disputes by drawing on the theoretical ideas of Foucault in relation to power and neo-liberal governance. Applying this to our dataset of 158 low-income workers who faced problems at work has enabled us to gain new insight into the dynamics of power affecting worker choices about how (if at all) to pursue their employment dispute.

It is clear that power relations are operating across a range of institutions and individuals. The traditional legal categories focusing primarily on interaction between employers and workers arose from a time of industrial capitalism. These need to be reviewed in the contemporary era. In this article, we have focused particularly on the role of the state and our findings reveal that it is extremely active in shaping the perspective of workers about what is the most appropriate course of action that they should take when facing a problem at work-even without particular pressure from the employer. The state does more than simply provide the structural and regulatory framework for managing disputes. It plays an ongoing role in the shaping of worker subjectivities regarding various inter-related issues, such as the importance of working, the need to be a particular type of worker, and the morality of asserting employment rights.

The role of the state can be seen more broadly in the changing nature of the civil justice framework and the increasing privatisation of dispute resolution. Although not the primary focus of the study reported here, our findings resonate with the observed trend of the 'disappearing civil trial. ${ }^{81}$ Genn identifies that such developments may: "lead to a lack of clarity in important areas of private law; that it has the potential to undermine the rule of law and that, together with the barriers that are being erected to access to justice for citizens, it will have a corrosive influence on public respect for and compliance with obligations and responsibilities under the law, and provide encouragement to those who would flout their legal responsibilities." ${ }^{\prime 2}$ The loss of labour law's public function is not a new phenomenon ${ }^{83}$ but the recent sweeping changes to the resolution process represented by the introduction of ET fees and, to a lesser extent, the promotion of Acas EC as an alternative to a full hearing have fundamentally altered the landscape within which resolution occurs. Genn's points seem particularly pertinent given the apparent suppression of the basic right to a full ET hearing. Interestingly, of the small minority of participants whose disputes made it all the way to a full

\footnotetext{
${ }^{80}$ Foucault, op. cit., n. 39.

${ }^{81}$ For US examples see: T.J. Stipanowich, 'ADR and the "Vanishing Trial": The Growth and Impact of “Alternative Dispute Resolution"', (2004) 1 J. of Empirical Legal Studies 843; M. Galanter, 'A World without Trials', (2006) 7 J. of Dispute Resolution 7. For UK examples see: H. Genn, Why the Privatisation of Civil Justice is a Rule of Law Issue, 36 ${ }^{\text {th }}$ F.A. Mann Lecture 2012; R. Dingwall and E. Cloatre, 'Vanishing Trials? An English perspective', (2006) $1 \mathrm{~J}$. of Dispute Resolution, 51.

82 Genn 2012, id., p3.

${ }^{83}$ K. Ewing , 'Democratic Socialism and Labour Law'(1995 ) 24 Industrial Law J. 103.
} 
hearing, there was typically an appreciation of symbolic importance of a respected independent decision-maker listening to their case and making a formal decision in light of the law on the matter.

Our findings have also alluded to the shifting nature of power relations as they operate in connection with employers. There have been important trends in the business world that affect who or what constitutes the employer and who influences employer decision making, all of which have repercussions in employment disputes. The contemporary employment context can involve: increasingly diverse forms of employing entities, such as agency arrangements, outsourcing and multinational interconnected corporate structures, ${ }^{84}$ a rise in shareholder power in the decision making of employing organisations; ${ }^{85}$ and the commodification of firms themselves to be bought and sold through mergers and acquisitions. ${ }^{86}$ This stands in stark contrast to traditional labour law assumptions about employers, which envisage an alignment within the same entity of the site of production, the economic decision making power in relation to the market, and financial governance. ${ }^{87}$

The effect of the contemporary context emerged in our findings in relation to the worker upset arising from a perceived breakdown of the appropriate basis of relations between a worker and their employer. Despite state efforts to promote economic rationality as the key criterion for decision making, workers continue to hold non-economic values regarding the employment relationship, such as expectations of respect, goodwill and trust. These are akin to the common law implied term of mutual trust and confidence. Workers' sense of these relations emerges out of the daily experience of going to work and interacting with ones' superiors. But for many of the workers in our study this mutuality appears to be stretched, stressed and tenuous. The expectation by workers of this mutuality remains, but the reciprocal sense from employers (broadly construed) may not be present or even legally required.

Our finding that the state is attempting to and, to a degree, is successful in, shaping the subjectivities of workers to influence their decision making has important implications for labour law and for conceptions of the role of law in society.

In terms of labour law, the shaping of workers' subjectivities to be in line with neo-liberal goals and values can detract from a sense of worker solidarity that operates to counterpose employer goals and objectives. A perceived alignment of goals-employers and workers being equally entrepreneurial-can mask key class and structural differences. If this is not identified as an issue, a response from the state or elsewhere is not warranted. Our findings demonstrate that many workers are indeed self-regulating their own behaviour so that it is in line with state objectives. This situation challenges labour lawyers to rethink how to achieve labour law's traditional aim of acting as a 'countervailing force' against the power of capital. What might it mean, for example, to act as a countervailing force against a neo-liberal oriented subjectivity held by a worker and which that worker views as coming from themselves? Or, perhaps more positively, how can the nagging anger that many workers experience when at the end of illegal practice by their employer be harnessed

\footnotetext{
${ }^{84}$ M. Morin, 'Labour Law and New Forms of Corporate Organization', (2005) 144 Industrial Law R. 1, 5. $85 \mathrm{Id}$.

${ }^{86}$ G. Standing, The Precariat: The New Dangerous Class (2014).

${ }^{87}$ Morin, op. cit., n. 84.
} 
and utilised as a powerful force? Labour lawyers can no longer view individual employment rights as protective or emancipatory in and of themselves. Rather, their utility needs to be considered in light of actual context-including power relations-in which workers may seek to assert them.

For legal scholars more broadly, the idea that the state can shape individual subjectivities regarding the law and legal disputes is important. We need to be increasingly aware of the broader context in which substantive law operates. This means being cognisant of the various 'truths' that surround a particular legal domain and the nuanced ways in which these truths become embedded in rhetoric and the practices of state institutions and other actors. We also need to look beyond the state's procedural framework which, despite giving the illusion of impartiality, strongly influences the actions taken by individuals. The possible courses of action are far from impartial. Rather they are strongly imbued with a moral tone which individuals perceive as coming from within themselves. People are largely unaware of the extent to which their decision-making is shaped by the state. Legal scholarship could benefit from a deeper exploration of these evolving subjectivities. 